\title{
An exploration of the factors discouraging Greenfield FDI in Greece
}

\author{
Vasileios A. Vlachos, Panagiotis Mitrakos, Chrysanthi Tsimpida, Antonis Tsitouras and Aristidis \\ Bitzenis
}

\begin{abstract}
Greece has suffered the worst from the late $2000 \mathrm{~s}$ global financial and economic crisis and despite the successful completion of the economic adjustment program in 2018 the rate of recovery in is still weak. Investment inflows by privatizations and/or other opportunities arising to foreign investors will accelerate the recovery rate of the Greek economy. However, the level of foreign direct investment (FDI) attracted by the Greek economy has always been well below the European Union average. This paper investigates the factors discouraging inward Greenfield FDI in Greece after the crisis.
\end{abstract}

Keywords - economic crisis, FDI, Greece, multinationals.

\section{INTRODUCTION}

The impact of the three interlocked facets (banking, sovereign debt and economic) of the late global financial and economic (henceforth) crisis that was triggered in 2007 had a negative effect on the economic performance of the European Union (EU). The speed of economic recovery in the EU and the euro area in the aftermath of the crisis has been less than satisfactory and full recovery remains still in question (Vlachos and Bitzenis, 2018). Although recovery in terms of gross domestic product (GDP) has been accelerating across the EU, investment recovery has been at a much slower pace due to differences in financing conditions for firms and the deleveraging process across the EU (European Investment Bank, 2017).

Greece has borne the brunt of this crisis. In the period 2007-2018 GDP fell by approximately 24 percent, and gross fixed capital formation by approximately 24 percent 65 percent (Eurostat database). Unemployment rates decreased under the 20 percent level in 2018. Despite the levels of weak recovery there is optimism that recovery will soon pick up as the economy becomes friendlier to investors through privatizations and the reduction of country risk (Vlachos et al., 2019).

However, there is still much to be done in order to boost the country's competitiveness. For example, according to the Ease of Doing Business Index of the World Bank, the Greek economy ranked on the 72nd place out of 190 economies in 2019 (International Bank for Reconstruction and Development, 2019, p. 5), achieving the lowest scores in the euro area. Empirical studies reveal that performance ratios/indices which

Aristidis Bitzenis, University of Macedonia, Thessaloniki, Greece.

Vasileios A. Vlachos, Panagiotis Mitrakos, Chrysanthi Tsimpida, Antonis Tsitouras, University of Macedonia, Thessaloniki, Greece. reflect the competitiveness of an economy, such as the World Bank's Ease of Doing Business indices can explain an economy's performance as a host for FDI (Jayasuriya, 2011; Corcoran and Gillanders, 2015).

This paper aims to survey the factors discouraging inward Greenfield FDI in Greece after the crisis. Greenfield investment is expected to have a direct positive effect on Greece's economic recovery. A questionnaire survey on the factors shaping the activity of multinationals in Greece is conducted on top management personnel of multinationals or their subsidiaries that have already invested in Greece. The exploration of the barriers that foreign investors face occurs through their own reflections on the Greek economy's shortcomings as a host. The findings provide orientations for policy makers to designate suitable reforms which will improve the competitiveness of the Greek economy and successfully remove the barriers to foreign investors.

The rest of the paper is organized as follows. The second section reviews studies on the factors determining FDI in EU and Greece. The third section presents the aim and the survey research method. The fourth section presents the results and discusses policy implications for the Greek government and for managers of multinationals interested in the Greek market.

\section{BACKGROUND}

There are several theoretical models exploring FDI determinants. For example, Faeth (2009) categorizes the literature of FDI determinants into 9 theoretical models and argues that empirical studies indicate the importance of these determinants in the real world. With regard to factors outside the theoretical models reviewed by Faeth (2009), Bénassy-Quéré et al. (2007) indicate that the quality of institutions is also important for attracting FDI and that two strands of literature on institutions and FDI have been developed: the study of the impact of source/host institutions on FDI, and the institutional distance between the source and host countries on FDI. Several more factors determining FDI activity may be identified as we move from the economics to the international business discipline, and Bitzenis (2003) and Bitzenis and Papadimitriou (2011) argue that there is no dominant theory and that the main aspects of each theory comprise what they term as the Universal Model of theories determining FDI. The Universal Model can be considered as less eclectic and more encompassing than Dunning's (2001) eclectic paradigm, and outlines the motives for FDI according to 
their content and categorizes them under the umbrellas of: market seekers, market seekers from a strategic point of view, factor seekers, efficiency seekers, locational seekers, exploitation of ownership advantages, financial aspects hunters, political reasons, and overcoming imperfections.

In contrast to the size of the literature on the factors determining FDI activity there are limited studies about the factors deterring FDI activity (excluding the research on trade and investment barriers). Accordingly, this section presents recent findings on the factors determining FDI in EU and Greece, and it is assumed that their absence deters inward FDI. With regard to recent studies (analyzing data for the global crisis) about the factors determining FDI in the EU, Weitzel et al (2014) examine data in 27 EU countries from 1999 to 2012. For countries with higher default risk and lower economic demand in the crisis, their results are consistent with the fire-sale hypothesis (countries affected by a crisis attract foreign buyers by selling assets at a discount). For countries with lower domestic credit, their results are in conflict with the notion of fire-sales (premiums are lower in crisis countries but do not drop further amid the crisis). Canton and Solera (2016) investigate the determinants of Greenfield FDI flows in EU member states using sectoral data on bilateral Greenfield FDI flows for the 2003-2014 period and find that regulations have a sizeable negative impact on FDI flows, taxes mainly matter for the decision to invest, the intensity of product market regulation mainly affect the size of the investment project, and the costs of contract enforcement matter for both the decision to invest and the size of the investment project. The European Commission (2017) published a report that analyzes the main barriers and drivers to investment in Europe and addresses the concerns about the EU investment rate being below its pre-crisis average and slowly recovering. The analysis highlights the regulatory framework, financial conditions, human capital and knowledge stocks, direct and indirect public intervention, and macroeconomic conditions as critical factors which differentiate across EU member states and shape the drivers and barriers to investment in tangible and intangible assets.

With regard to the factors determining FDI activity in Greece, Vlachos et al. (2019, pp. 274-275) review the studies about the determinants of inward FDI in Greece, and indicate that several studies suffer from aggregation bias and/or lack the analysis of the distinction between the decision to invest and how much to invest, and find that market size and market growth, economies of scale, productivity, human capital, sunk costs degree of openness, political and economic stability, and links with neighboring states are the most important factors driving Greece's inward FDI activity. Only three studies about the determinants of inward FDI in Greece (see Table I) analyze primary collected data (Bitzenis et al., 2007; Vlachos et al., 2018; Vlachos et al., 2019). Bitzenis et al. (2007) analyze the decision of 52 multinationals to invest in Greece during the period 1995-2003 and find that the top 10 motives were prospects for market growth, political stability, economic stability, market size, social stability, 2004 Olympiad, links with neighboring states, international pressures, establishing an export base, and economies of scale. Vlachos et al. (2019) investigate the factors favoring inward FDI in Greece after the crisis and find from data collected from 62 multinationals that foreign investors do not consider that the Greek economy has important advantages (notable in importance being the geographical proximity of Greece to EU and the links of Greece to other neighboring countries, Greece's cultural similarities/closeness and expected economic growth).

Vlachos et al. (2018) analyze the factors that favor and discourage FDI in Greece and find from data collected from 34 multinationals that expected economic growth, geographical proximity to EU, links of Greece to other neighboring countries, cultural similarities/closeness, availability of skilled workers, low cost of skilled labor, and availability of labor force, all appear to be important in determining inward FDI. In addition, bureaucracy, lack of transparency, macroeconomic instability, corruptive/criminal practices, and an unstable legal framework, all appear to have a critical role in discouraging foreign investors. In an earlier study of the factors deterring FDI activity in Greece, Bitzenis et al. (2009) analyze data collected from 52 multinationals during 1995-2003 and find that bureaucracy, taxation, corruption, labor market structure and the instability of the legal system as the main barriers to inward FDI in Greece. 
Authors, dependent variable and data set

Filippaios (2006). Inward FDI position per industry from 15 source states over the period 1996-2001 (fixed effects model).

Bitzenis et al. (2007). The decision of 52 multinationals to invest in Greece during the period 1995-2003 (cross-tabulation analysis).

Pantelidis and Nikolopoulos (2008). Inward FDI for the period 1976-2004 (OLS analysis of quarterly data).

Leitao (2010). FDI flows during the period 1998-2007 (panel data analysis).

Petrakou (2013). FDI stock per capita in 10 industries of 25 Greek prefectures (NUTS level 3 regions) for 2008, employing stock data from 2004 (cross-section GLS analysis).

Pantelidis and Paneta (2016). Inward FDI for the period 1982-2013 (OLS analysis of quarterly data).

Vogiatzoglou and Tsekeris (2016). Inward FDI stock for 14 manufacturing industries during the period 2001-2012 (panel data analysis).

Vlachos et al. (2018). Factors favoring the activity of multinationals in Greece (exploratory survey).

Vlachos et al. (2019). Factors favoring inward FDI in Greece after the crisis (matching, Friedman test, Wilcoxon signed-rank test).

\section{Results}

Host GDP, industry productivity of fixed capital, EU origin (not periphery) of the investor, all have a positive impact on Greece's industry inward FDI position.

The top 10 motives for FDI in Greece are prospects for market growth, political stability, economic stability, market size, social stability, 2004 Olympiad, links with neighboring states, international pressures, establishing an export base, and economies of scale.

Market size, technological capabilities, human capital, and economic activity, all have a positive impact on Greece's inward FDI.

Previous FDI, market size, openness and inflation, all have a positive effect on inward FDI.

GDP per capita as a proxy for a region's level of development, population potential index as a proxy for regional market size, gravity index as a proxy for the region's central or peripheral position in the national economic space, share of population with tertiary education as a proxy for human capital, revealed comparative advantage index as a proxy for the degree of industry specialization of each region in terms of employment, spatial clustering indicator, are all found to be statistically significant and have a positive effect on FDI.

Gross national income, exchange rate and openness of the economy are all positively associated with FDI.

Industry value added as a proxy for industry size, industry's R\&D intensity, wage cost, labor productivity, economies of scale, industry's raw materials intensity, industry's energy intensity, revenue from outsourcing intensity, all have a positive effect on inward FDI.

Expected economic growth, geographical proximity to EU, links of Greece to other neighboring countries, cultural similarities/closeness, availability of skilled workers, low cost of skilled labor, and availability of labor force.

Foreign investors do not consider that the Greek economy has important advantages.

\section{METHOD}

This study aims is to investigate the factors discouraging inward Greenfield FDI in Greece in the aftermath of the global crisis. A questionnaire survey on the factors shaping the activity of multinationals in Greece is conducted on top management personnel of multinationals or their subsidiaries that have already invested in Greece. The construction of the questionnaire is based on the following elements:

- Firstly, the perspectives and the theoretical backgrounds of previous studies on barriers to Greece's FDI attractiveness based on the analysis of primary data (Bitzenis et al., 2009). The experience from past surveys (Bitzenis et al., 2009) is materialized as the blueprint of the questionnaire for this study.

- Secondly, the theoretical considerations of the universal model of FDI activity (Bitzenis and Papadimitriou, 2011).

- Thirdly, emphasis is given on the factors affecting FDI analyzed by the European Commission (2017) report (all factors are explored by the questionnaire used in this study).

The questionnaires were aimed towards top management personnel of multinationals or their subsidiaries operating in Greece, and include questions about the nature, performance, and goals of multinationals/subsidiaries and the factors discouraging FDI in Greece. The factors ratings take the values 1 (not important) and 2 (important). The sample has been determined on a quota basis. The selection of cases is not random and is based on the identification of specific characteristics in order to increase representativeness. This is achieved through the inclusion of multinationals or their subsidiaries from different types of industries, their volume of investments, and the number of their employees (information about foreign investors provided by a specialist management advisory services organization). The outcome of 235 cases occurred from questionnaires filled-out online via an exclusive link provided. The size of the primary data collected is phenomenal compared to the size of primary data collected in previous studies concerning Greece.

\section{FINDINGS \& CONCLUSIONS}

Table II presents the barriers to inward Greenfield FDI projects in Greece, as indicated by their top management personnel. The threshold frequency of 50.1 percent indicates that more than half of the cases indicate that the barrier is important. Henceforth the barriers with a frequency above this threshold are only considered to be important (for the majority of cases).

The decisive barriers (representing more than 80 percent of the sample) to Greece's inward Greenfield FDI are those of bureaucracy, political instability, lack of enforcement of the laws and lack of transparency. Very important barriers (representing approximately $70 \%$ of the sample) are the 
unstable legal framework, excessive taxation, corruption, low credit rating of the country and macroeconomic instability. The findings indicate that foreign investors undertaking Greenfield projects are more concerned about institutional performance and stability (for example, political stability and law enforcement).

Compared to previous studies (Bitzenis et al., 2009) the findings indicate that bureaucracy, corruption and the instability of the legal system are still significant barriers to inward FDI in Greece, as well as taxation is. It becomes straightforward that policy makers need to be a lot more active regarding these areas, when considering that the significant barriers are almost similar after a decade, and that there is an expectation that the gradual reduction of country risk (and the course towards investment grade rating) will also reduce the barriers to Greece's inward FDI (Vlachos, 2019). The findings indicate that brave reforms are needed to battle the factors contributing to Greece's poor levels of competitiveness (for example, as indicated by the World Bank's Ease of Doing Business 2019 indices). These factors concern the performance of institutions (for example, bureaucracy, corruption, and law enforcement) and the stability of the political and the economic environment. Another factor also harming Greece's competitiveness that should not be ignored is the high level of taxation.

TABLE II: BARRIERS TO GREECE'S INWARD GREENFIELD FDI

Indicator/Statistic

Bureaucracy

Political instability

Lack of enforcement of

the laws

Lack of transparency

Unstable legal framework

Excessive taxation

Corruptive / Criminal

practices

Low credit rating of the

country

Macroeconomic

instability

Lack of managerial skills

Lack of financial

resources

No sound banking system

Negative attitude to

foreign investors

Underdeveloped business

infrastructure

\begin{tabular}{ccc}
$\begin{array}{c}\text { Frequency } \\
\text { (percent) } \\
93,8\end{array}$ & Mean & $\begin{array}{c}\text { Std. } \\
\text { Deviation }\end{array}$ \\
87,5 & 1,94 & 0,250 \\
87,5 & 1,88 & 0,342 \\
81,3 & 1,81 & 0,342 \\
75,0 & 1,75 & 0,403 \\
75,0 & 1,75 & 0,447 \\
68,8 & 1,69 & 0,479 \\
68,8 & 1,69 & 0,479 \\
68,8 & 1,69 & 0,479 \\
62,5 & 1,63 & 0,500 \\
62,5 & 1,63 & 0,500 \\
62,5 & 1,63 & 0,500 \\
56,3 & 1,56 & 0,512 \\
56,3 & 1,56 & 0,512 \\
\hline
\end{tabular}

There must be political consensus over a plan of reforms to battle these factors in order to attract strategic investors for the completion of the privatization programs. The privatization programs have to be completed to start the rebalance of the economy to higher value added services and products and signal to international strategic investors to consider the Greek firms, which not only survived the worst crisis, but also improved their own competitiveness.

Finally, adopting a stable tax system over a long-term horizon, stop the practice of tax amnesties, and gradually lowering the compliance costs will inevitably increase compliance and tax revenues, and gradually reduce the size of uncollected taxes. As more firms comply and employ fewer resources for their tax compliance, they will dedicate resources to productive practices.

\section{ACKNOWLEDGEMENTS}

"This research is co-financed by Greece and the European Union (European Social Fund-ESF) through the Operational Programme «Human Resources Development, Education and Lifelong Learning 2014-2020» in the context of the project "An Investigation of FDI Deterrents in Greece for the Formulation of a Realistic Reform Framework to Restart the Economy"(MIS 5006421).

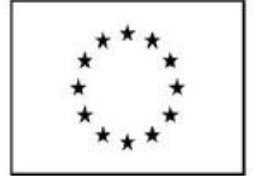

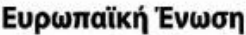
European Social Fund
Operational Programme Human Resources Development, Education and Lifelong Learning

Co-financed by Greece and the European Union

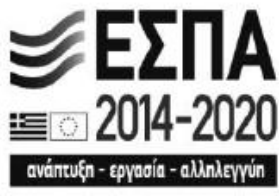




\section{REFERENCES}

[1] Bénassy-Quéré, A., Coupet, M. and Mayer, T. (2007). Institutional determinants of foreign direct investment. World Economy, 30 (5), pp. 764-782. https://doi.org/10.1111/j.1467-9701.2007.01022.x

[2] Bitzenis, A. (2003). Universal model of theories determining FDI. Is there any dominant theory? Are the FDI inflows in the CEE countries and especially in Bulgaria a myth? European Business Review, 15 (2), pp. 94-104. https://doi.org/10.1108/09555340310464722

[3] Bitzenis, A. and Papadimitriou, P. (2011). The universal model of theories determining FDI revisited. International Journal of Trade and Global Markets, 4 (4), pp. 350-371. https://doi.org/10.1504/IJTGM.2011.042861

[4] Bitzenis, A., Tsitouras, A. and Vlachos, V.A. (2007). Motives for FDI in a small EMU member state: The case of Greece. East-West Journal of Economics and Business, 10 (2), pp. 11-42.

[5] Bitzenis, A., Tsitouras, A. and Vlachos, V.A. (2009). Decisive FDI obstacles as an explanatory reason for limited FDI inflows in an EMU member state: The case of Greece. Journal of Socio-Economics, 38 (4), pp. 691-704.

https://doi.org/10.1016/j.socec.2009.03.001

[6] Canton, E., and Solera, I. (2016). Greenfield foreign direct investment and structural reforms in Europe: What factors determine investments? European Economy Discussion Paper No. 33, Luxembourg: Publications Office of the European Union.

[7] Corcoran, A. and Gillanders, R. (2015), Foreign direct investment and the ease of doing business. Review of World Economics, 151 (1), pp. 103-126. https://doi.org/10.1007/s10290-014-0194-5

[8] Faeth, I. (2009). Determinants of foreign direct investment - A tale of nine theoretical models. Journal of Economic Surveys, 23 (1), pp. 165-196. https://doi.org/10.1111/j.1467-6419.2008.00560.x

[9] Dunning, J. H. (2001). The eclectic (OLI) paradigm of international production: Past, present and future. International Journal of the Economics of Business, 8 (2), pp. 173-190. https://doi.org/10.1080/13571510110051441

[10] European Commission (2017). Investment in the EU Member States: An analysis of drivers and barriers. Institutional Paper 062. Publications Office of the European Union, Luxembourg. Available online at https://ec.europa.eu/info/sites/info/files/ip062_en.pdf (accessed 19 June 2019).

[11] European Investment Bank (2017). EIB Investment Report 2017/2018: From recovery to sustainable growth. European Investment Bank, Luxembourg.

[12] International Bank for Reconstruction and Development (2019). Doing Business 2019: Training for Reform. World Bank Publications, Washington DC.

[13] Jayasuriya, D. (2011), Improvements in the World Bank's Ease of Doing Business rankings: Do they translate into greater foreign direct investment inflows? World Bank Policy Research Working Paper No. 5787. World Bank, Washington DC. https://doi.org/10.1596/1813-9450-5787

[14] Vlachos, V.A. and Bitzenis, A. (2018). The (reinvigorating) role of foreign direct investment after the crisis. Journal of East-West Business, 24 (3), pp. 139-143.

[15] Vlachos, V.A., Mitrakos, P., Tsimpida, C., Tsitouras A. and Bitzenis, A. (2018). Factors favoring and discouraging inward FDI in Greece. Global Business \& Economics Anthology, 2018 (2), 36-41 https://doi.org/10.1080/10669868.2018.1459130

[16] Vlachos, V.A., Mitrakos, P., Tsimpida, C., Tsitouras A. and Bitzenis, A. (2019). Factors favoring foreign direct investment in Greece aftermath of the global financial crisis: An exploratory survey. Journal of East-West Business, 25 (3), pp. 262-292. https://doi.org/10.1080/10669868.2019.1616647

[17] Weitzel, U., Kling, G. and Gerritsen, D. (2014). Testing the fire-sale FDI hypothesis for the European financial crisis. Journal of International Money and Finance, 49 (Part B), pp. 211-234. https://doi.org/10.1016/j.jimonfin.2014.03.011 